ARTICLE

\title{
The impact of nitrogen oxides on electrochemical carbon dioxide reduction
}

\author{
Byung Hee Ko (i) ${ }^{1}$, Bjorn Hasa (i) ${ }^{1}$, Haeun Shin (10) ${ }^{1}$, Emily Jeng (i) $^{1}$, Sean Overa (i) ${ }^{1}$, Wilson Chen (1) ${ }^{1} \&$ \\ Feng Jiao (1) ${ }^{1 凶}$
}

The electroreduction of carbon dioxide offers a promising avenue to produce valuable fuels and chemicals using greenhouse gas carbon dioxide as the carbon feedstock. Because industrial carbon dioxide point sources often contain numerous contaminants, such as nitrogen oxides, understanding the potential impact of contaminants on carbon dioxide electrolysis is crucial for practical applications. Herein, we investigate the impact of various nitrogen oxides, including nitric oxide, nitrogen dioxide, and nitrous oxide, on carbon dioxide electroreduction on three model electrocatalysts (i.e., copper, silver, and tin). We demonstrate that the presence of nitrogen oxides (up to $0.83 \%$ ) in the carbon dioxide feed leads to a considerable Faradaic efficiency loss in carbon dioxide electroreduction, which is caused by the preferential electroreduction of nitrogen oxides over carbon dioxide. The primary products of nitrogen oxides electroreduction include nitrous oxide, nitrogen, hydroxylamine, and ammonia. Despite the loss in Faradaic efficiency, the electrocatalysts exhibit similar carbon dioxide reduction performances once a pure carbon dioxide feed is restored, indicating a negligible long-term impact of nitrogen oxides on the catalytic properties of the model catalysts.

\footnotetext{
${ }^{1}$ Center for Catalytic Science and Technology, Department of Chemical and Biomolecular Engineering, University of Delaware, Newark, DE 19716, USA.

凶email: jiao@udel.edu
} 
T he electrochemical $\mathrm{CO}_{2}$ reduction $\left(\mathrm{CO}_{2} \mathrm{RR}\right)$ provides a promising, sustainable avenue to generate value-added fuels and chemicals from greenhouse gas $\mathrm{CO}_{2}{ }^{1,2}$. Depending on the choice of electrocatalyst, $\mathrm{CO}_{2}$ can be converted into a variety of single-carbon $\left(\mathrm{C}_{1}\right.$; e.g., carbon monoxide, formic acid, methanol, and methane) and multi-carbon $\left(\mathrm{C}_{2+}\right.$; e.g., ethylene, ethanol, acetate, and n-propanol) products with tremendous market potentials ${ }^{3-8}$. While $\mathrm{CO}_{2} \mathrm{RR}$ is being actively studied, most studies are conducted using highly pure $\mathrm{CO}_{2}$ feed $^{9,10}$. For commercial applications, the most commonly available $\mathrm{CO}_{2}$ sources are industrial point sources, such as chemical and power plants; ${ }^{11}$ however, $\mathrm{CO}_{2}$ gas emitted from these sources often contain a variety of contaminants, such as sulfur oxides $\left(\mathrm{SO}_{\mathrm{x}}\right)$, nitrogen oxides $\left(\mathrm{NO}_{\mathrm{x}}\right), \mathrm{O}_{2}$, and volatile organic compounds (VOC) (Fig. 1a) ${ }^{12-14}$. Therefore, there is an urgent need to understand the potential impact of common contaminants in industrial $\mathrm{CO}_{2}$ sources on the catalyst properties in $\mathrm{CO}_{2} \mathrm{RR}$.

Gas impurity in $\mathrm{CO}_{2}$ can affect the performance of $\mathrm{CO}_{2} \mathrm{RR}$ electrocatalysts as we demonstrated in the case of $\mathrm{SO}_{2}{ }^{15}$, where a trace amount of $\mathrm{SO}_{2}$ in the feed is sufficient to alter the product selectivity of $\mathrm{Cu}$ catalyst substantially. The potential impacts of impurity include lowering Faradaic efficiency (FE; i.e., number of electrons transferred to desired products divided by the total number of electrons passed in the system) due to competing reactions of impurity over $\mathrm{CO}_{2}$, altering the property of the catalyst by incorporating into the catalyst and/or support, and adsorbing on the catalyst surface to physically block the active sites (Fig. 1a). To date, there are only a few studies focusing on understanding how the presence of contaminants influences the behavior of electrocatalysts under $\mathrm{CO}_{2} \mathrm{RR}$ conditions ${ }^{15-21}$. For example, $\mathrm{NO}_{\mathrm{x}}$ is one of the major contaminants present in industrial $\mathrm{CO}_{2}$ point sources with a typical concentration of 1000 $\mathrm{ppm}^{12-14}$. The $\mathrm{NO}_{\mathrm{x}}$ contaminants typically consist of $90-95 \%$ nitric oxide (NO) and 5-10\% nitrogen dioxide $\left(\mathrm{NO}_{2}\right)^{22}$. Additionally, nitrous oxide $\left(\mathrm{N}_{2} \mathrm{O}\right)$ is also a common byproduct formed in the $\mathrm{NO}_{\mathrm{x}}$ removal process ${ }^{23}$, which has a relatively low reactivity in comparison to other $\mathrm{NO}_{\mathrm{x}}$. A previous study has shown that $200 \mathrm{ppm}$ of $\mathrm{NO}$ has a negligible influence on Cu catalysts in $\mathrm{CO}_{2} \mathrm{RR}$ in a conventional batch cell ${ }^{18}$. Furthermore, less than or equal to $1667 \mathrm{ppm}$ of $\mathrm{NO}_{2}$ has shown to be either beneficial or neutral, and greater than $1667 \mathrm{ppm}$ of $\mathrm{NO}_{2}$ has shown to be detrimental in $\mathrm{CO}_{2} \mathrm{RR}$, mainly due to a reduction in $\mathrm{pH}$ of the electrolyte, also on $\mathrm{Cu}$ catalysts in a conventional batch cell ${ }^{19}$. However, the behavior of various $\mathrm{NO}_{\mathrm{x}}$ impurities in $\mathrm{CO}_{2} \mathrm{RR}$ at industrially relevant high current densities $\left(>100 \mathrm{~mA} \mathrm{~cm}^{-2}\right)$ has not been explored yet.

In this work, we investigate the influence of $\mathrm{NO}_{\mathrm{x}}$ (i.e., $\mathrm{NO}$, $\mathrm{NO}_{2}$, and $\mathrm{N}_{2} \mathrm{O}$ ) in $\mathrm{CO}_{2} \mathrm{RR}$ using a three-compartment flow cell. Three model electrocatalysts, including copper $(\mathrm{Cu})$, silver $(\mathrm{Ag})$, and tin $(\mathrm{Sn})$, are selected to represent the most studied catalysts for $\mathrm{C}_{2+}$ products, carbon monoxide (CO), and formate, respectively. Most $\mathrm{NO}_{\mathrm{x}}$ contaminants in the $\mathrm{CO}_{2}$ feed significantly reduce the $\mathrm{CO}_{2} \mathrm{RR}$ FE because the electrochemical reduction of $\mathrm{NO}_{\mathrm{x}}$ occurs at much more positive potentials than $\mathrm{CO}_{2} \mathrm{RR}$ (Fig. 1b). $\mathrm{NO}$ and $\mathrm{NO}_{2}$ impurities have more severe impacts on $\mathrm{CO}_{2} \mathrm{RR}$ FE than $\mathrm{N}_{2} \mathrm{O}$, likely due to the greater number of electrons required in the $\mathrm{NO}_{\mathrm{x}}$ reactions. Despite the loss of $\mathrm{CO}_{2} \mathrm{RR}$ $\mathrm{FE}$, none of the three catalysts exhibits a significant change of product selectivity after removing the $\mathrm{NO}_{\mathrm{x}}$ impurity from the
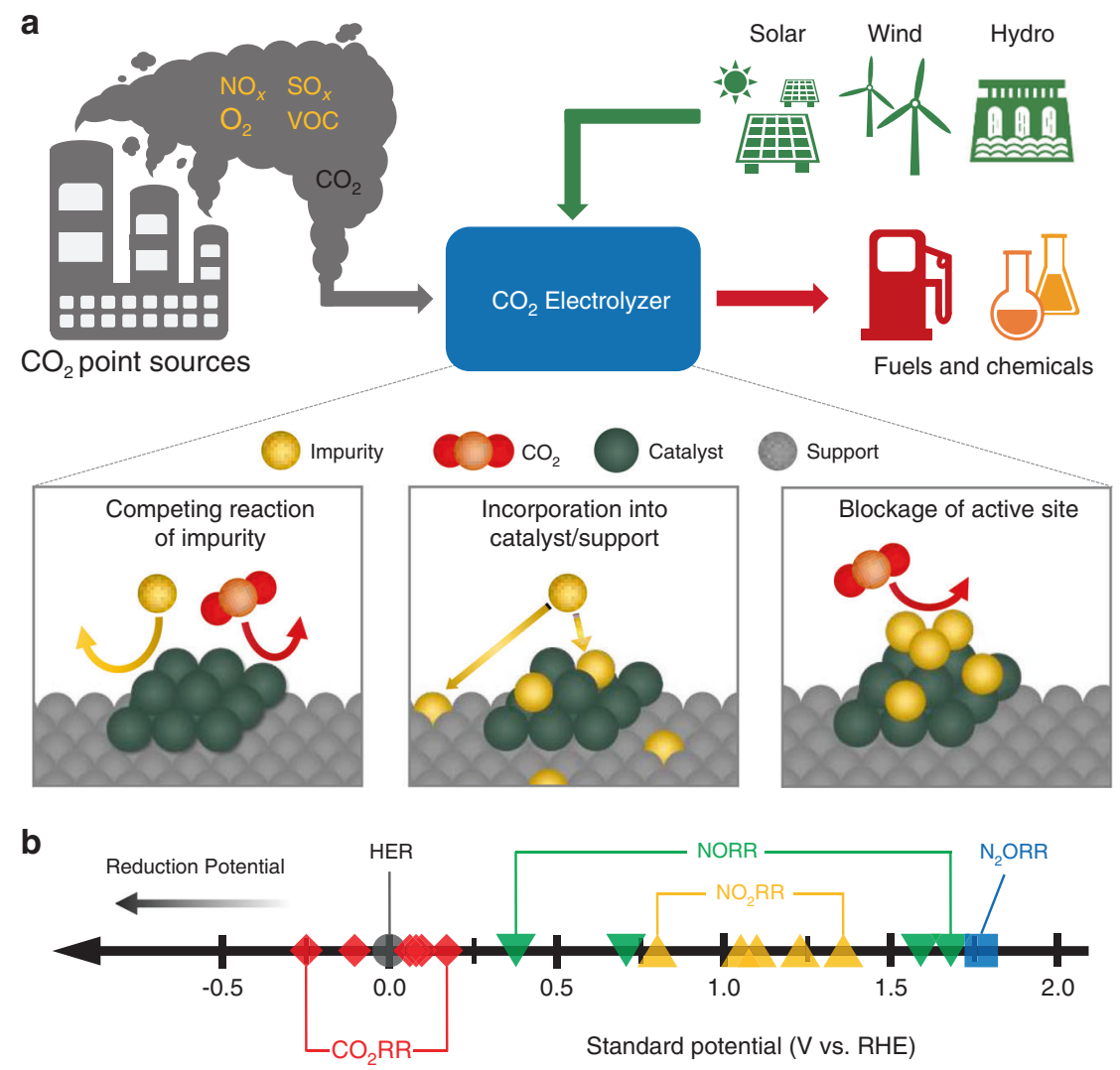

Fig. $1 \mathrm{CO}_{\mathbf{2}}$ electrolysis technology using industrial $\mathrm{CO}_{\mathbf{2}}$ point sources. (a) Schematics of $\mathrm{CO}_{2}$ electrolysis with $\mathrm{CO}_{2}$ stream obtained from point sources containing impurities such as nitrogen oxides $\left(\mathrm{NO}_{x}\right)$, sulfur oxides $\left(\mathrm{SO}_{\mathrm{x}}\right), \mathrm{O}_{2}$, and volatile organic compounds (VOC) and potential influence of impurities in $\mathrm{CO}_{2}$ electroreduction $\left(\mathrm{CO}_{2} \mathrm{RR}\right)$. (b) Standard potential vs. reversible hydrogen electrode (RHE) for $\mathrm{CO}_{2} \mathrm{RR}$, hydrogen evolution reaction $(\mathrm{HER})$, $\mathrm{NO} \mathrm{O}_{2}$ reduction $\left(\mathrm{NO}_{2} \mathrm{RR}\right), \mathrm{NO}$ reduction (NORR), and $\mathrm{N}_{2} \mathrm{O}$ reduction $\left(\mathrm{N}_{2} \mathrm{ORR}\right)$. Detailed reactions are provided in Supplementary Table 1. 
$\mathrm{CO}_{2}$ feed. Moreover, we employ gas chromatography (GC), spectrophotometry, and flow electrochemical mass spectrometry (FEMS) to analyze the products of electroreduction of $\mathrm{NO}$, the dominant component of $\mathrm{NO}_{\mathrm{x}}$ in industrial point sources, in which the major products are ammonia $\left(\mathrm{NH}_{3}\right)$, hydroxylamine $\left(\mathrm{NH}_{2} \mathrm{OH}\right), \mathrm{N}_{2}$, and $\mathrm{N}_{2} \mathrm{O}$. Investigation of the effect of different concentrations of $\mathrm{NO}$ in $\mathrm{CO}_{2} \mathrm{RR}$ shows that $\mathrm{NO}_{\mathrm{x}}$ at typical concentrations in flue gases is compatible with $\mathrm{CO}_{2} \mathrm{RR}$.

\section{Results and Discussion}

Electrodes were prepared by loading commercial $\mathrm{Cu}, \mathrm{Ag}$, and Sn particles on a gas diffusion layer (GDL), a microporous carbon paper which provides mechanical support, electrical conductivity, and hydrophobicity. Scanning electron microscopy (SEM) images of the as-prepared electrodes confirm a uniform deposition of metal nanoparticles on GDL, covering the majority of the GDL surface (Supplementary Fig. 1). Electrochemical experiment was performed in a three-compartment flow cell, in which $\mathrm{CO}_{2}$ gas is directly fed to the electrodeelectrolyte interface, enabling $\mathrm{CO}_{2} \mathrm{RR}$ at high current densities (Supplementary Fig. 2). $\mathrm{NO}_{\mathrm{x}}$ impurities were mixed with $\mathrm{CO}_{2}$ gas feed prior to entering the flow cell. As the concentration of $\mathrm{NO}_{\mathrm{x}}$ in typical exhaust streams may be as high as $\sim 3,000 \mathrm{ppm}$ (i.e., 0.3 vol. $\%)^{13}$, conservative streams of $83.3 \% \mathrm{CO}_{2}, 15.87 \%$ $\mathrm{Ar}$, and $0.83 \% \mathrm{NO}_{\mathrm{x}}$ were used for most studies. To keep the $\mathrm{CO}_{2}$ partial pressure constant during the introduction of $\mathrm{NO}_{\mathrm{x}}$, which contains $\mathrm{Ar}, \mathrm{CO}_{2}$ partial pressure was maintained at 0.833 bar throughout the study by using a mixture of $83.3 \%$ $\mathrm{CO}_{2}$ and $16.7 \% \mathrm{Ar}$ when $\mathrm{NO}_{\mathrm{x}}$ was not introduced.

Impact of $\mathrm{NO}_{x}$ impurities on $\mathbf{C O}_{2}$ electroreduction. The influence of $\mathrm{NO}$ in $\mathrm{CO}_{2} \mathrm{RR}$ on $\mathrm{Cu}, \mathrm{Ag}$, and $\mathrm{Sn}$ catalysts was first evaluated at a constant current density of $100 \mathrm{~mA} \mathrm{~cm}^{-2}$ (Fig. 2a-c). The $\mathrm{CO}_{2} \mathrm{RR}$ experiment was performed by switching the gas feed from $83.3 \% \mathrm{CO}_{2}$ and $16.7 \% \mathrm{Ar}(0-0.5 \mathrm{~h})$ to $83.3 \%$ $\mathrm{CO}_{2}, 15.87 \% \mathrm{Ar}$, and $0.83 \% \mathrm{NO}$ (green region; $0.5-1 \mathrm{~h}$ ) and back to $83.3 \% \mathrm{CO}_{2}$ and $16.7 \% \mathrm{Ar}(1-3 \mathrm{~h})$. With $83.3 \% \mathrm{CO}_{2}$ and $16.7 \%$ $\mathrm{Ar}$, before exposure to $\mathrm{NO}, \mathrm{Cu}$ catalyst produced a wide range of $\mathrm{C}_{1}$ (i.e., methane, $\mathrm{CO}$, and formate) and $\mathrm{C}_{2+}$ (i.e., ethylene, ethanol, acetate, and propanol) products. In the cases of $\mathrm{Ag}$ and Sn catalysts, the major products were $\mathrm{CO}$ and formate, respectively. The observed $\mathrm{CO}_{2} \mathrm{RR}$ selectivity of the $\mathrm{Cu}, \mathrm{Ag}$, and $\mathrm{Sn}$ catalysts was consistent with the previous reports ${ }^{6,7}$.

When $0.83 \% \mathrm{NO}$ was introduced at $t=0.5 \mathrm{~h}$, the total $\mathrm{CO}_{2} \mathrm{RR}$ FE decreased noticeably on all three catalysts (Fig. 2a-c). On average, the losses in $\mathrm{CO}_{2} \mathrm{RR} F E$ accounted for 33.9, 29.6, and $27.9 \%$ on $\mathrm{Cu}, \mathrm{Ag}$, and $\mathrm{Sn}$, respectively (Fig. 2d), which is likely due to the preferential reduction of $\mathrm{NO}$ over $\mathrm{CO}_{2}$. Assuming $\mathrm{NO}$ is fully converted to $\mathrm{NH}_{3}$, conversions of $\mathrm{NO}$ during $\mathrm{CO}_{2} \mathrm{RR}$ are between $48 \%$ and $60 \%$ (Supplementary Table 5). As shown in Fig. 1b, the standard potentials of NORR are much more positive than those of $\mathrm{CO}_{2} \mathrm{RR}$. For instance, the standard potential of NORR to $\mathrm{N}_{2}$ is $1.68 \mathrm{~V}$ vs. RHE, while the standard potentials of $\mathrm{CO}_{2} \mathrm{RR}$ are between -0.250 and $0.169 \mathrm{~V}$ vs. RHE. Cyclic voltammetry $(\mathrm{CV})$ measurements under $\mathrm{CO}_{2}$ with $0.83 \% \mathrm{NO}$ also confirmed that NORR is more favorable than $\mathrm{CO}_{2} \mathrm{RR}$ on $\mathrm{Cu}$, $\mathrm{Ag}$, and Sn catalysts (Supplementary Fig. 3). On all three catalysts, onset potentials and cathodic currents shifted to more positive potentials when $0.83 \% \mathrm{NO}$ was introduced to the $\mathrm{CO}_{2}$ stream. CV measurements under different concentrations of $\mathrm{NO}$ in $\mathrm{Ar}$ also confirmed more positive onset potentials of NORR than $\mathrm{CO}_{2} \mathrm{RR}$ and showed that NORR at $0.83 \% \mathrm{NO}$ is mass transport limited (Supplementary Fig. 4). After restoring $83.3 \% \mathrm{CO}_{2}$ and $16.7 \% \mathrm{Ar}$, the $\mathrm{CO}_{2} \mathrm{RR}$ performance and the total $\mathrm{CO}_{2} \mathrm{RR} \mathrm{FE}$ on all three catalysts quickly recovered and were stable for additional $2 \mathrm{~h}$ of electrolysis. No obvious change in selectivity was observed for any of the three catalysts, suggesting that the exposure to NO did not alter the catalyst property in any significant way. There is a slight increase in $\mathrm{H}_{2}$ FE over time (Fig. $2 \mathrm{a}-\mathrm{c}$ ), but it is likely due to the slow flooding of the electrode (Supplementary Fig. 5) 24 .

To obtain insight on the influence of $\mathrm{NO}_{\mathrm{x}}$ in $\mathrm{CO}_{2} \mathrm{RR}$ at typical concentrations of $\mathrm{NO}_{\mathrm{x}}$ in point sources, we evaluated the effect of $0.083 \%$ and $0.0083 \% \mathrm{NO}$, representing the typical $\mathrm{NO}_{\mathrm{x}}$ concentrations in flue gases and flue gases after $\mathrm{NO}_{\mathrm{x}}$ removal processes $^{22}$, respectively, in $\mathrm{CO}_{2} \mathrm{RR}$ (Fig. 2d). Although the losses in $\mathrm{FE}$ at $0.83 \% \mathrm{NO}$ were detrimental, the effect of $\mathrm{NO}$ was less severe at $0.083 \%$, with less than $5 \%$ losses in $\mathrm{FE}$, and negligible at $0.0083 \%$ NO. Therefore, $\mathrm{NO}$ at typical concentrations of $\mathrm{NO}_{\mathrm{x}}$ in flue gases is compatible with $\mathrm{CO}_{2} \mathrm{RR}$, although complete removal of $\mathrm{NO}_{\mathrm{x}}$ is desired to maximize $\mathrm{CO}_{2} \mathrm{RR} \mathrm{FE}$.

$\mathrm{NO}_{2}$ is another major contaminant in industrial $\mathrm{CO}_{2}$ point sources $\left(5-10 \%\right.$ of $\left.\mathrm{NO}_{\mathrm{x}}\right)$, and a substantial amount of $\mathrm{N}_{2} \mathrm{O}$ may also be formed as a byproduct during the $\mathrm{NO}_{\mathrm{x}}$ removal process ${ }^{22,23}$. Thus, we further investigated the influence of $\mathrm{NO}_{2}$ and $\mathrm{N}_{2} \mathrm{O}$ in $\mathrm{CO}_{2} \mathrm{RR}$ on $\mathrm{Cu}, \mathrm{Ag}$, and $\mathrm{Sn}$ catalysts following the similar experimental procedure to the $\mathrm{NO}$ experiment. When $0.83 \% \mathrm{NO}_{2}$ was introduced at $t=0.5 \mathrm{~h}$ (yellow region), the $\mathrm{CO}_{2} \mathrm{RR}$ FE decreased on all three catalysts (Fig. 3a). The decrease in the total FEs were $30.8,25.6$, and $22.9 \%$ on $\mathrm{Cu}, \mathrm{Ag}$, and $\mathrm{Sn}$ catalysts, respectively. Similarly, when $0.83 \% \mathrm{~N}_{2} \mathrm{O}$ was introduced (blue region), the total $\mathrm{CO}_{2} \mathrm{RR}$ FE decreased by $11.4,10.2$, and $1.4 \%$ on $\mathrm{Cu}, \mathrm{Ag}$, and $\mathrm{Sn}$ catalysts, respectively (Fig. 3b). Distinct from $\mathrm{Cu}$ and $\mathrm{Ag}$ catalysts, Sn catalyst did not show a significant loss of the $\mathrm{CO}_{2} \mathrm{RR} F E$ in the presence of $\mathrm{N}_{2} \mathrm{O}$, which is likely due to the poor activity of $\mathrm{Sn}$ for $\mathrm{N}_{2} \mathrm{ORR}^{25}$. Sn catalyst maintained a high $\mathrm{CO}_{2} \mathrm{RR} \mathrm{FE}$ over the course of $3 \mathrm{~h}$ of electrolysis, suggesting the resistive feature of $\mathrm{Sn}$ catalyst to $\mathrm{N}_{2} \mathrm{O}$ impurity. As shown in Fig. 1b, standard potentials of $\mathrm{NO}_{2}$ and $\mathrm{N}_{2} \mathrm{O}$ are also more positive than those of $\mathrm{CO}_{2} \mathrm{RR}$, and therefore, we attribute the loss of the $\mathrm{CO}_{2} \mathrm{RR}$ FE to the preferential reduction of $\mathrm{NO}_{2}$ and $\mathrm{N}_{2} \mathrm{O}$ over $\mathrm{CO}_{2}$, which is further supported by the $\mathrm{CV}$ study (Supplementary Figs. 8-11). When a pure $\mathrm{CO}_{2}$ feed was restored, the total $\mathrm{CO}_{2} \mathrm{RR} \mathrm{FE}$ on all three catalysts quickly recovered, suggesting that the exposure of $\mathrm{NO}_{2}$ and $\mathrm{N}_{2} \mathrm{O}$ does not affect the property of the catalysts.

A comparison of the losses in $\mathrm{FE}$ due to the various $\mathrm{NO}_{\mathrm{x}}$ impurities is presented in Fig. 3c. $\mathrm{NO}$ and $\mathrm{NO}_{2}$ show greater losses in $\mathrm{FE}$ than $\mathrm{N}_{2} \mathrm{O}$ on all three catalysts, likely due to the greater number of electrons required in the reactions. As will be discussed in the following section, the main products of NORR are $\mathrm{NH}_{3}$ and $\mathrm{NH}_{2} \mathrm{OH}$, which require 5 and 3 electrons, respectively, while the main product of $\mathrm{N}_{2} \mathrm{ORR}$ is $\mathrm{N}_{2}$, which only requires 2 electrons. Given that all $\mathrm{NO}_{\mathrm{x}}$ readily reacts at the catalyst surface, the same amount of $\mathrm{NO}$ and $\mathrm{NO}_{2}$ consume more electrons than $\mathrm{N}_{2} \mathrm{O}$, causing greater losses in $\mathrm{CO}_{2} \mathrm{RR}$ FE. Among all the catalysts, the $\mathrm{Cu}$ catalyst suffers the largest $\mathrm{FE}$ loss on all $\mathrm{NO}_{\mathrm{x}}$ impurities, followed by $\mathrm{Ag}$ and $\mathrm{Sn}$ catalysts. Indeed, $\mathrm{Cu}$ has been demonstrated as one of the more active metals for the electroreduction of $\mathrm{NO}^{26}$ and $\mathrm{N}_{2} \mathrm{O}^{25}$, in which $\mathrm{Cu}$ achieved high FE in $\mathrm{N}_{2} \mathrm{ORR}$ to $\mathrm{N}_{2}$ at relatively low overpotentials. The results suggest that $\mathrm{Cu}$ is an effective electrocatalyst for $\mathrm{NO}_{\mathrm{x}}$ reduction, which may be further explored in future studies.

Furthermore, $\mathrm{pH}$ was measured at the outlet of the electrolyzer at different time points (i.e., before, during, and after $\mathrm{NO}_{\mathrm{x}}$ introduction) to investigate the effect of $\mathrm{NO}_{\mathrm{x}}$ on the electrolyte $\mathrm{pH}$ (Supplementary Fig. 12). The measured $\mathrm{pH}$ shows that the presence of $\mathrm{NO}$ and $\mathrm{N}_{2} \mathrm{O}$ has a negligible effect on the $\mathrm{pH}$, while the presence of $\mathrm{NO}_{2}$ slightly decreases the $\mathrm{pH}$ by 0.03 . Although $\mathrm{NO}_{2}$ hydrolyzes to produce nitric acid and nitrous acid 27 , the effect in $\mathrm{pH}$ is very small, possibly due to the small amount of $\mathrm{NO}_{2}$ in the gas feed, rapid reaction of $\mathrm{NO}_{2}$ at the catalyst surface 

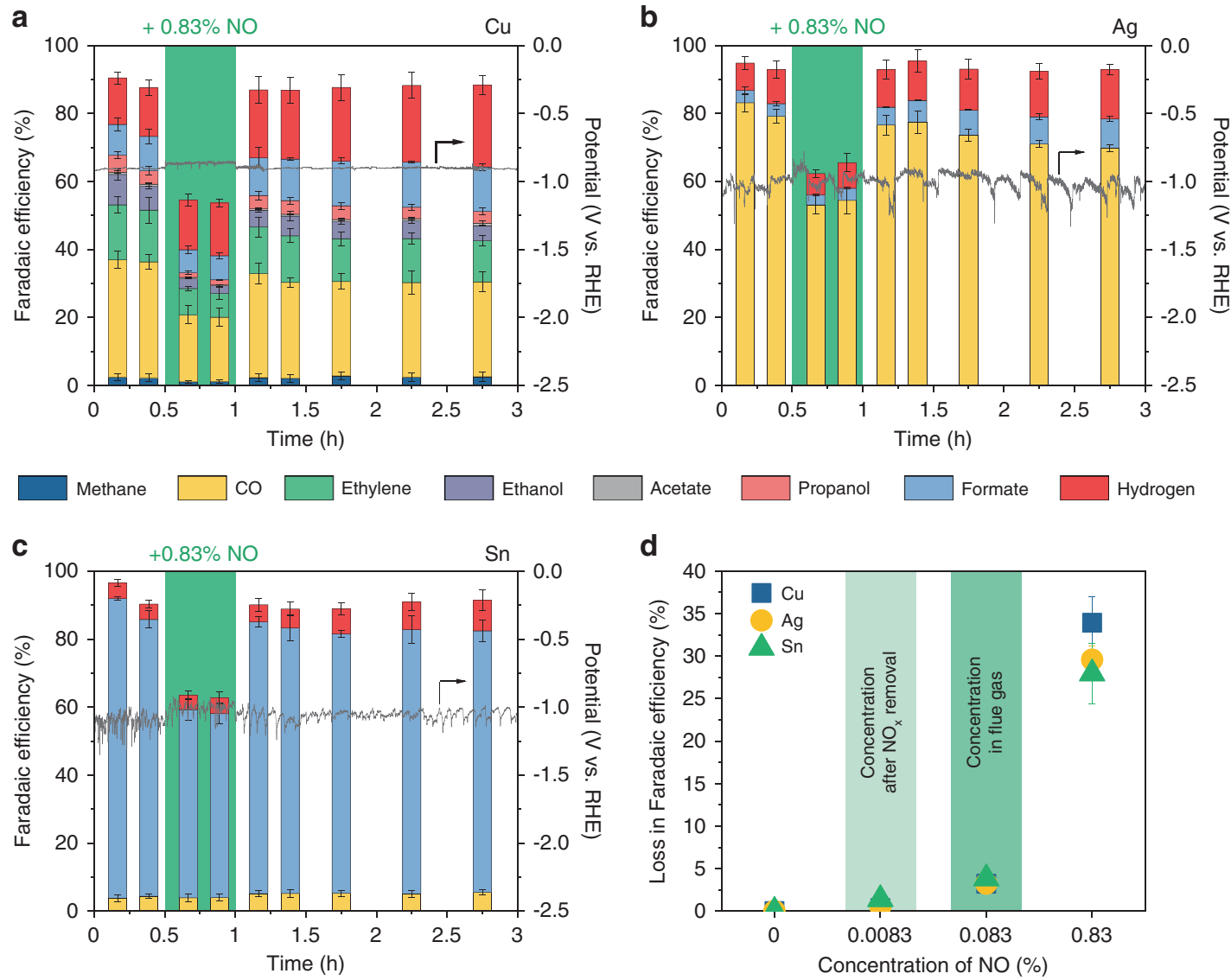

Fig. $2 \mathbf{C O}_{2}$ electroreduction performance in the presence of NO. Faradaic efficiency and applied potential vs. time on (a) $\mathrm{Cu},(\mathbf{b}) \mathrm{Ag}$, and (c) $\mathrm{Sn}$ catalysts at a constant current density of $100 \mathrm{~mA} \mathrm{~cm}^{-2}$ in $1 \mathrm{M} \mathrm{KHCO}_{3}$ for $3 \mathrm{~h}$. Gas feeds were $83.3 \% \mathrm{CO}_{2}$ and $16.7 \% \mathrm{Ar}$, and $83.3 \% \mathrm{CO}_{2}, 15.87 \% \mathrm{Ar}$, and $0.83 \% \mathrm{NO}$ (green). $0.83 \% \mathrm{NO}$ was introduced at $0.5 \mathrm{~h}$ for $0.5 \mathrm{~h}$. Corresponding Faradaic efficiencies are provided in Supplementary Tables 2-4. (d) Effect of different concentrations of $\mathrm{NO}$ in $\mathrm{CO}_{2}$ electroreduction on $\mathrm{Cu}, \mathrm{Ag}$, and $\mathrm{Sn}$ catalysts. $0.083 \%$ and $0.0083 \%$ represent the typical $\mathrm{NO}_{x}$ concentrations in flue gases and flue gases after $\mathrm{NO}_{x}$ removal processes, respectively. Corresponding Faradaic efficiencies are provided in Supplementary Table 6 . Error bars represent the standard deviation of three independent measurements.

a

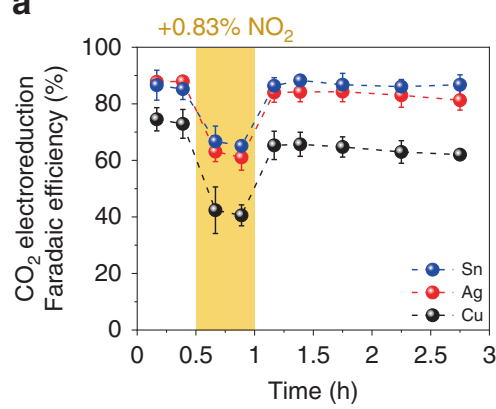

b

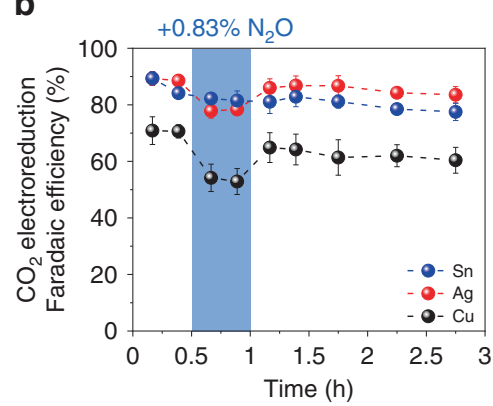



Fig. $3 \mathbf{C O}_{\mathbf{2}}$ electroreduction performance in the presence of $\mathbf{N O}_{\mathbf{2}}$ and $\mathbf{N}_{\mathbf{2}} \mathbf{O} . \mathrm{CO}_{2}$ electroreduction Faradaic efficiency, excluding hydrogen Faradaic efficiency, vs. time with the introduction of (a) $0.83 \% \mathrm{NO}_{2}$ (yellow) and (b) $0.83 \% \mathrm{~N}_{2} \mathrm{O}$ (blue) on $\mathrm{Cu}, \mathrm{Ag}$, and Sn catalysts at a constant current density of $100 \mathrm{~mA} \mathrm{~cm}^{-2}$ in $1 \mathrm{M} \mathrm{KHCO}_{3}$ for $3 \mathrm{~h}$. Gas feeds were $83.3 \% \mathrm{CO}_{2}$ and $16.7 \% \mathrm{Ar}$, and $83.3 \% \mathrm{CO}_{2}$ and $15.87 \% \mathrm{Ar}$ with $0.83 \% \mathrm{NO}_{2}$ or $0.83 \% \mathrm{~N}_{2} \mathrm{O}$. $\mathrm{NO}_{2}$ and $\mathrm{N}_{2} \mathrm{O}$ were introduced at $t=0.5 \mathrm{~h}$ for $0.5 \mathrm{~h}$. Corresponding Faradaic efficiencies are provided in Supplementary Figs. 6 and 7, and Supplementary Tables 712. (c) Loss in Faradaic efficiency during $\mathrm{CO}_{2}$ electroreduction from the introduction of $0.83 \% \mathrm{NO}, 0.83 \% \mathrm{NO}_{2}$, and $0.83 \% \mathrm{~N}_{2} \mathrm{O}$ on $\mathrm{Cu}, \mathrm{Ag}$, and $\mathrm{Sn}$ catalysts. Corresponding Faradaic efficiencies are provided in Supplementary Table 13. Error bars represent the standard deviation of three independent measurements.

which prevents $\mathrm{NO}_{2}$ from penetrating to the bulk electrolyte, and a flowing electrolyte which is constantly replenished.

Identification of $\mathrm{NO}_{\mathrm{x}}$ reduction products. The electrochemical reduction products of $\mathrm{NO}$, the major component of $\mathrm{NO}_{\mathrm{x}}$ in industrial point sources, were further investigated. As $\mathrm{NH}_{3}$,
$\mathrm{NH}_{2} \mathrm{OH}, \mathrm{N}_{2}$, and $\mathrm{N}_{2} \mathrm{O}$ have been suggested as the main products in $\mathrm{NORR}^{26,28,29}, \mathrm{NH}_{3}$ and $\mathrm{NH}_{2} \mathrm{OH}$ were detected via spectrophotometry (Supplementary Figs. 13 and 14), and $\mathrm{N}_{2}$ was detected via GC (Supplementary Fig. 15). We note that the concentration of $\mathrm{N}_{2} \mathrm{O}$ in the gas product stream was below the detection limit of $\mathrm{GC}$, suggesting that $\mathrm{N}_{2} \mathrm{O}$ FE was below $2 \% \mathrm{FE}$ 
a
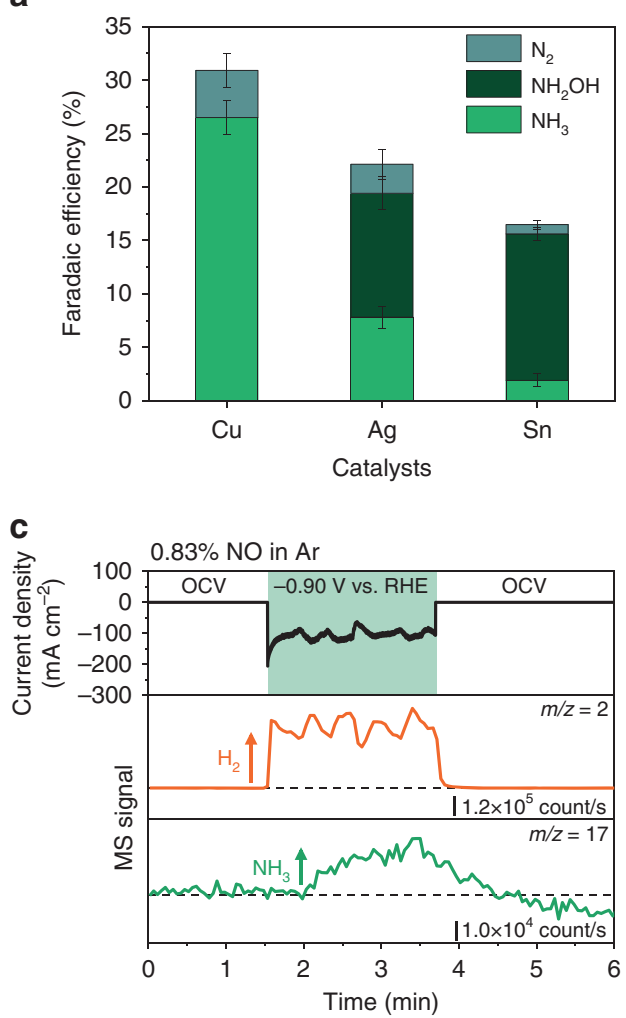

b

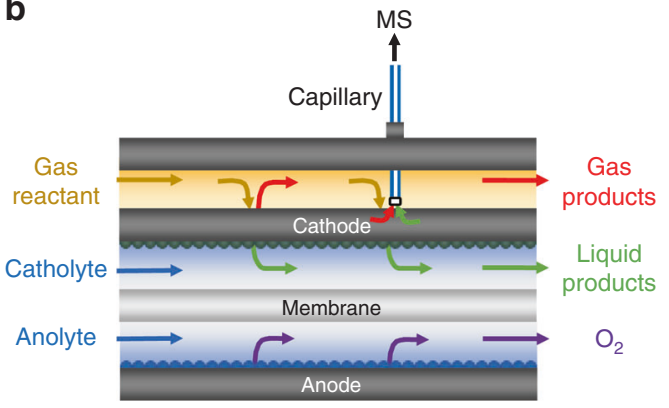

d



Fig. 4 Investigation of the NO electroreduction products. (a) Faradaic efficiency of NO electroreduction products produced during electrolysis with $83.3 \% \mathrm{CO}_{2}, 15.87 \% \mathrm{Ar}$, and $0.83 \% \mathrm{NO}$ on $\mathrm{Cu}, \mathrm{Ag}$, and $\mathrm{Sn}$ catalysts at a constant current density of $100 \mathrm{~mA} \mathrm{~cm}{ }^{-2}$ in $1 \mathrm{M} \mathrm{KHCO}_{3}$ for $3 \mathrm{~h}$. Corresponding Faradaic efficiencies are provided in Supplementary Table 14. Error bars represent the standard deviation of three independent measurements. (b) Schematic of flow electrochemical mass spectrometry (FEMS) setup. (c) Measured current density vs. time, and deconvoluted MS signal vs. time for $m / z=2, m / z=17$, (d) $m / z=28, m / z=30$, and $m / z=44$ from FEMS on Cu catalyst in $1 \mathrm{M} \mathrm{KHCO}_{3}$ with $0.83 \%$ NO in Ar. -0.90 V vs. RHE was applied for approximately $2 \mathrm{~min}$ starting at $t=1.5 \mathrm{~min}$. NORR products have been deconvoluted using the mass spectra of individual products shown in Supplementary Fig. 17. Additional information is provided in the Methods section and Supplementary Figs. 18 and 19.

on all three catalysts. As shown in Fig. 4a, NORR product selectivity varied among different catalysts. $\mathrm{Cu}$ primarily produced $\mathrm{NH}_{3}$ and $\mathrm{N}_{2}$, with no $\mathrm{NH}_{2} \mathrm{OH}, \mathrm{Ag}$ produced a mixture of NORR products, and $\mathrm{Sn}$ primarily produced $\mathrm{NH}_{2} \mathrm{OH}$. These observations are consistent with previous reports, in which $\mathrm{Cu}$ has been demonstrated as an effective catalyst for NORR to $\mathrm{NH}_{3}{ }^{26}$, and $\mathrm{Sn}$ has been used as a dopant in Pt to shift the selectivity from $\mathrm{NH}_{3}$ to $\mathrm{NH}_{2} \mathrm{OH}$ in nitrate reduction ${ }^{30}$.

To further probe the formation of NORR products with greater sensitivity and determine the formation of $\mathrm{N}_{2} \mathrm{O}$, we employed the FEMS (Fig. 4b and Supplementary Fig. 16), which allows us to continuously measure gas and volatile liquid products operando with a low detection limit and a short response time by continuously pulling products to the mass spectrometry (MS) near the surface of the electrodes (See Methods for more details). The MS probe was placed near the working electrode from the gas channel side, and the MS signals linked to possible products were tracked over time. We conducted the FEMS measurement on the $\mathrm{Cu}$ catalyst using $0.83 \% \mathrm{NO}$ in $\mathrm{Ar}$ (in the absence of $\mathrm{CO}_{2}$ ), because the ionization of $\mathrm{N}_{2}(\mathrm{~m} / z=28,14)$ and $\mathrm{N}_{2} \mathrm{O}(\mathrm{m} / z=44$, $30,28,14)$ produces the same fragments with $\mathrm{CO}_{2}$ and various $\mathrm{CO}_{2}$ reduction products ${ }^{31-33}$, complicating the reliable analysis of the NORR products (see Supplementary Note for more details). MS signals of the FEMS measurement under a continuous feed of $0.83 \% \mathrm{NO}$ are presented in Fig. $4 \mathrm{c}$, d. When a constant potential of $-0.90 \mathrm{~V}$ vs. RHE was applied at $t=1.5$ for $\sim 2 \mathrm{~min}$, MS signals of $\mathrm{NO}(m / z=30)$ decreased while those of $\mathrm{H}_{2}(\mathrm{~m} / z=2), \mathrm{NH}_{3}$ $(m / z=17), \mathrm{N}_{2}(m / z=28)$ and $\mathrm{N}_{2} \mathrm{O}(m / z=44)$ increased (Fig. $4 \mathrm{c}$, d), indicating the consumption of $\mathrm{NO}$ and the formation of $\mathrm{H}_{2}$, $\mathrm{NH}_{3}, \mathrm{~N}_{2}$, and $\mathrm{N}_{2} \mathrm{O}$. The formation of $\mathrm{NH}_{3}$ and $\mathrm{N}_{2}$ detected by FEMS is in agreement with the results obtained from spectrophotometry and GC analysis, respectively. The production of $\mathrm{N}_{2} \mathrm{O}$, which was difficult to measure via GC, was clearly observed in FEMS, suggesting that $\mathrm{N}_{2} \mathrm{O}$ is one of the NORR products. $\mathrm{NH}_{2} \mathrm{OH}$ was not detected in FEMS, because it is nonvolatile ${ }^{30}$. Similarly, FEMS results also suggest the formation of $\mathrm{N}_{2}$ and $\mathrm{N}_{2} \mathrm{O}$ on $\mathrm{Ag}$ and Sn catalysts (Supplementary Figs. 20-25). However, the formation of $\mathrm{NH}_{3}$ was observed only on $\mathrm{Ag}$ and not on $\mathrm{Sn}$, likely due to the small amount of $\mathrm{NH}_{3}$ produced on Sn. Collectively, $\mathrm{NH}_{3}, \mathrm{NH}_{2} \mathrm{OH}, \mathrm{N}_{2}$, and $\mathrm{N}_{2} \mathrm{O}$ have been determined as the NORR products. The analysis of the NORR products further confirms that the loss in $\mathrm{CO}_{2} \mathrm{RR} \mathrm{FE}$ is due to the preferential reduction of $\mathrm{NO}$ over $\mathrm{CO}_{2}$.

In the case of $\mathrm{N}_{2} \mathrm{ORR}$, a substantial amount of $\mathrm{N}_{2}$ was quantified with a GC (Supplementary Fig. 26). While the losses of $\mathrm{CO}_{2} \mathrm{RR} \mathrm{FE}$ were $11.4 \%, 10.2 \%$, and $1.4 \%$ on $\mathrm{Cu}, \mathrm{Ag}$, and $\mathrm{Sn}$ catalysts, respectively, the amounts of $\mathrm{N}_{2}$ detected were $8.2 \%$, $7.3 \%$, and $0.5 \%$ of the total $\mathrm{FE}$, respectively, accounting for the majority of the loss in the $\mathrm{CO}_{2} \mathrm{RR}$ FE. Small amount of $\mathrm{N}_{2}$ detected on $\mathrm{Sn}$ catalyst demonstrates the resistive nature of $\mathrm{Sn}$ catalyst in $\mathrm{N}_{2} \mathrm{ORR}$.

Characterization of catalyst structures in the presence of $\mathrm{NO}_{\mathrm{x}}$. $\mathrm{X}$-ray photoelectron spectroscopy (XPS) measurements were conducted to reveal the influence of $\mathrm{NO}_{\mathrm{x}}$ on the surface electronic 

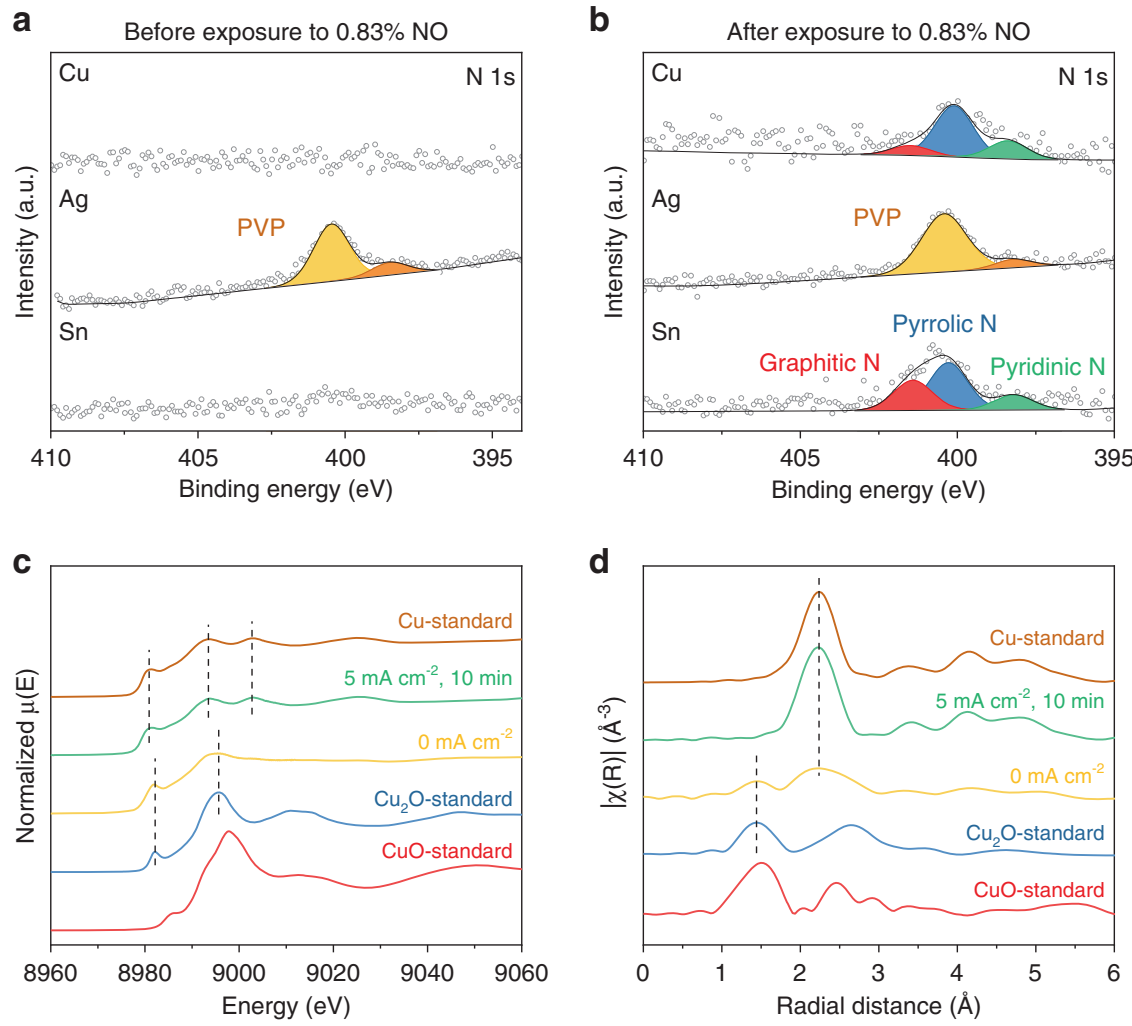

Fig. 5 Evaluation of the influence of $\mathbf{N O}$ on the catalyst structure. XPS measurements of $\mathrm{Cu}, \mathrm{Ag}$, and $\mathrm{Sn}$ electrodes (a) before ( $t=0 \mathrm{~h})$ and $(\mathbf{b})$ after exposure to $0.83 \% \mathrm{NO}(t=1 \mathrm{~h})$ during $\mathrm{CO}_{2}$ electrolysis. Corresponding XPS data is provided in Supplementary Fig. 27 and Supplementary Table 15. Cu Kedge (c) XANES and (d) EXAFS spectra of spent $\mathrm{Cu}$ catalyst after exposure to $0.83 \% \mathrm{NO}$ during $\mathrm{CO}_{2}$ electrolysis. $\mathrm{Cu}$ foil, $\mathrm{Cu}_{2} \mathrm{O}$, and $\mathrm{CuO}$ were used as references.

structure and the chemical environment of the catalysts. The samples were obtained at various points of the $\mathrm{CO}_{2} \mathrm{RR}$ experiment, including before exposure to $\mathrm{NO}_{\mathrm{x}}$, after exposure to $\mathrm{NO}_{\mathrm{x}}$, and at the end of 3-h electrolysis. As shown in Fig. 5a, the $\mathrm{Cu}$ and Sn electrodes before the exposure to $\mathrm{NO}_{\mathrm{x}}$ did not show any noticeable peak in $\mathrm{N} 1 \mathrm{~s}$ XPS measurements. In contrast, Ag showed two distinct peaks at $400.5 \mathrm{eV}$ and $398.5 \mathrm{eV}$, which can be attributed to polyvinylpyrrolidone (PVP) $)^{34,35}$, a surfactant used in the nanoparticle synthesis. The XPS measurements obtained after the NO exposure $(t=1 \mathrm{~h})$ exhibited new $\mathrm{N} 1 \mathrm{~s}$ peaks on $\mathrm{Cu}$ and $\mathrm{Sn}$ electrodes (Fig. 5b). The peaks at $401.4 \mathrm{eV}, 400.2 \mathrm{eV}$, and $398.2 \mathrm{eV}$ can be assigned to graphitic, pyrrolic, and pyridinic $\mathrm{N}$, respectively ${ }^{36,37}$, suggesting that incorporated $\mathrm{N}$ atoms mainly interact with carbon in GDL rather than metal catalysts (metal nitride peaks typically observed near $397 \mathrm{eV})^{38,39}$. The XPS measurements obtained after 3-h electrolysis show that the $\mathrm{N}$ incorporated in the electrode surface was still intact after additional $2 \mathrm{~h}$ of $\mathrm{CO}_{2} \mathrm{RR}$ (Supplementary Fig. 27 and Supplementary Table 15), with the total amount of $\mathrm{N}$ in the $\mathrm{Cu}$ and $\mathrm{Sn}$ electrodes remaining relatively unchanged. In the cases of $0.83 \% \mathrm{NO}_{2}$ and $0.83 \% \mathrm{~N}_{2} \mathrm{O}$, the XPS measurements show similar $\mathrm{N}$ incorporation in GDL (Supplementary Figs. 28 and 29, and Supplementary Tables 16 and 17). Regarding the Ag electrode, the XPS investigation of $\mathrm{N}$ incorporation associated with $\mathrm{NO}_{\mathrm{x}}$ was largely limited by the presence of the PVP surfactant.

To further confirm the incorporation of $\mathrm{N}$ into GDL rather than the formation of metal nitrides, we increased the catalyst loading to $2.0 \mathrm{mg} \mathrm{cm}^{-2}$, which created a thick layer of catalyst on the GDL with much less exposure of GDL in the XPS measurement. After exposure to $0.83 \%$ NO during $\mathrm{CO}_{2}$ electrolysis, the $\mathrm{N} 1 \mathrm{~s}$ signal was not detected on the $\mathrm{Cu}$ and $\mathrm{Sn}$ electrodes with the increased catalyst loading, whereas the XPS measurements for the Ag electrode clearly shows the N 1 s signal, which is due to the presence of PVP on the surface of Ag catalyst (Supplementary Fig. 30). Conversely, when the same experiment was repeated with GDL without any catalyst, $\mathrm{N}$ species was still detected, confirming the incorporation of $\mathrm{N}$ into GDL (Supplementary Fig. 30). Experiments using $\mathrm{NO}_{2}$ and $\mathrm{N}_{2} \mathrm{O}$ show similar incorporation of $\mathrm{N}$ into GDL (Supplementary Fig. 30).

To probe the influence of $\mathrm{NO}_{\mathrm{x}}$ impurity on the oxidation state of the $\mathrm{Cu}$ catalyst, we conducted X-ray absorption spectroscopy (XAS) measurements using a customized XAS batch cell (Supplementary Fig. 31). Because of the toxicity of the $\mathrm{NO}_{x}$ gases, we did not use the $\mathrm{NO}_{\mathrm{x}}$ gases directly at the synchrotron $\mathrm{X}$ ray beamline but conducted XAS experiments with the electrodes taken out of the electrolyzer at $1 \mathrm{~h}$ (after exposure to $\mathrm{NO}_{\mathrm{x}}$ for $0.5 \mathrm{~h}$ ) during $\mathrm{CO}_{2}+\mathrm{NO}_{\mathrm{x}}$ experiments (Fig. 2a-c and Supplementary Figs. 6 and 7). The Cu K-edge X-ray absorption nearedge spectroscopy (XANES) spectra of the $\mathrm{Cu}$ catalyst after the NO exposure show a similar spectrum of the $\mathrm{Cu}_{2} \mathrm{O}$ standard, suggesting an average $\mathrm{Cu}$ oxidation state of +1 (Fig. $5 \mathrm{c}$ ). Extended X-ray absorption fine structure (EXAFS) result shows that the NO-exposed $\mathrm{Cu}$ sample contains a mixture of $\mathrm{Cu}$ and $\mathrm{Cu}_{2} \mathrm{O}$ (Fig. 5d). Slight oxidation of $\mathrm{Cu}$ is likely due to the exposure of the sample in the air during sample handling. After a constant current density of $5 \mathrm{~mA} \mathrm{~cm}{ }^{-2}$ was applied under $\mathrm{CO}_{2} \mathrm{RR}$ condition, the $\mathrm{Cu}$ catalyst was quickly reduced to metallic $\mathrm{Cu}$, suggesting that a small amount of current is sufficient to fully reduce the $\mathrm{Cu}$ catalyst under $\mathrm{CO}_{2} \mathrm{RR}$ conditions. XAS measurements on $\mathrm{Cu}$ samples exposed to $\mathrm{NO}_{2}$ and $\mathrm{N}_{2} \mathrm{O}$ also exhibited similar behaviors as the NO-treated $\mathrm{Cu}$ sample (Supplementary Figs. 32 and 33), confirming that the $\mathrm{Cu}$ catalyst remains or revert to fully metallic under reaction conditions after $\mathrm{NO}_{\mathrm{x}}$ is removed from the $\mathrm{CO}_{2}$ stream. 
Moreover, ex-situ SEM images were obtained at various points of the experiment to evaluate the impact of $\mathrm{NO}_{\mathrm{x}}$ on the catalyst morphology. SEM images of the spent catalysts after the exposure to $\mathrm{NO}_{\mathrm{x}}$ impurities $(t=1 \mathrm{~h}$ and $3 \mathrm{~h})$ exhibit minimal changes in $\mathrm{Cu}$ and $\mathrm{Ag}$ catalysts (Supplementary Figs. 1, 34, and 35). Although an increase in particle size was observed in the case of Sn catalysts (Supplementary Figs. 1 and 36), the Sn sample obtained after $1 \mathrm{~h}$ of $\mathrm{CO}_{2}$ electrolysis in the absence of $\mathrm{NO}_{\mathrm{x}}$ also showed a similar increase in particle size (Supplementary Fig. 37). The Sn particles likely aggregated to lower the surface energy under $\mathrm{CO}_{2} \mathrm{RR}$ condition regardless of $\mathrm{NO}_{\mathrm{x}}$, and therefore, $\mathrm{NO}_{\mathrm{x}}$ impurities are not the primary cause of the size change of the $\mathrm{Sn}$ particles during $\mathrm{CO}_{2} \mathrm{RR}$. These results suggest that the presence of $\mathrm{NO}_{\mathrm{x}}$ during $\mathrm{CO}_{2} \mathrm{RR}$ has a negligible impact on the catalyst morphology.

\section{Conclusions}

In summary, we investigated the influence of various $\mathrm{NO}_{\mathrm{x}}$ (i.e., $\mathrm{NO}, \mathrm{NO}_{2}$, and $\mathrm{N}_{2} \mathrm{O}$ ) in $\mathrm{CO}_{2} \mathrm{RR}$ on $\mathrm{Cu}, \mathrm{Ag}$, and $\mathrm{Sn}$ catalysts in a flow cell. The presence of $\mathrm{NO}_{x}$ impurities reduced the $\mathrm{CO}_{2} \mathrm{RR} F E$ due to the preferential reduction of $\mathrm{NO}_{\mathrm{x}}$ over $\mathrm{CO}_{2}$. The impact of $\mathrm{NO}$ and $\mathrm{NO}_{2}$ is more severe than that of $\mathrm{N}_{2} \mathrm{O}$ in $\mathrm{CO}_{2} \mathrm{RR}$ due to the greater number electrons involved in NORR and $\mathrm{NO}_{2} \mathrm{RR}$ compared to $\mathrm{N}_{2} \mathrm{ORR}$. The major NORR products are $\mathrm{NH}_{3}$, $\mathrm{NH}_{2} \mathrm{OH}, \mathrm{N}_{2}$, and $\mathrm{N}_{2} \mathrm{O}$, in which the selectivity varies among different catalysts, whereas $\mathrm{N}_{2} \mathrm{O}$ is primarily reduced to $\mathrm{N}_{2}$. Despite the loss of $\mathrm{CO}_{2} \mathrm{RR} F E$, a small amount of $\mathrm{NO}_{\mathrm{x}}$ in the $\mathrm{CO}_{2}$ feed does not alter the metallic nature of the catalyst under $\mathrm{CO}_{2} \mathrm{RR}$ conditions as demonstrated by the XPS and XAS measurements. Furthermore, although high concentrations of $\mathrm{NO}_{\mathrm{x}}$ may be detrimental to $\mathrm{CO}_{2} \mathrm{RR}, \mathrm{NO}_{\mathrm{x}}$ at typical concentrations of flue gases is compatible with $\mathrm{CO}_{2} \mathrm{RR}$, causing small losses in $\mathrm{CO}_{2} \mathrm{RR}$ FE. $\mathrm{NO}_{\mathrm{x}}$ removal process, which is a relatively mature technology, may also be employed to ensure $\mathrm{CO}_{2} \mathrm{RR}$ operation at maximum efficiency. This work not only demonstrates the effect of a trace amount of $\mathrm{NO}_{\mathrm{x}}$ impurities that are often present in the industrial $\mathrm{CO}_{2}$ point sources on the most commonly studied metal catalysts, but also offers new insights on the electrochemical reduction of $\mathrm{NO}_{\mathrm{x}}$, which has rarely been explored in the literature.

\section{Methods}

Electrode preparation. Commercial Cu (25 nm, Sigma-Aldrich), Ag (<100 nm, 99.5\%, Sigma-Aldrich), and Sn $(0.1 \mu \mathrm{m}$, Alfa Aesar) particles were used as cathode catalysts. Commercial $\mathrm{IrO}_{2}$ (99.99\%, Alfa Aesar) was used as an anode catalyst. The catalyst inks were prepared by dissolving $3 \mathrm{mg}$ of the catalyst and $20 \mu \mathrm{l}$ of Nafion ( 5 weight \% in 50/50 water and isopropanol) in $3 \mathrm{~mL}$ of isopropanol. The catalyst ink was sonicated for at least $30 \mathrm{~min}$, and $0.25 \mathrm{mg} \mathrm{cm}^{-2}$ of the catalyst was drop casted onto a Sigracet 29 BC GDL (Fuel Cell Store).

Flow cell electrolysis. The electrochemical measurements were conducted in a three-compartment flow cell with channel dimensions of $2 \mathrm{~cm}$ by $0.5 \mathrm{~cm}$ by $0.15 \mathrm{~cm}$ (Supplementary Fig. 2). The electrode area was $1 \mathrm{~cm}^{2}$ and the distance between the electrode and the membrane was $0.15 \mathrm{~cm}$. A FAA-3-hydroxide exchange membrane (Fumatech) was used to separate electrolyte in the anode and the cathode chamber. $1 \mathrm{M} \mathrm{KHCO}_{3}$ was prepared by purging $\mathrm{CO}_{2}$ (Matheson, $99.999 \%$ ) into potassium carbonate (99\%, Alfa Aesar) and purified using a Chelex 100 sodium salt (Sigma Aldrich). After filtering Chelex 100 sodium salt, $1 \mathrm{M} \mathrm{KHCO}_{3}$ was used as an electrolyte for both catholyte and anolyte and was fed at $0.9 \mathrm{~mL} \mathrm{~min}^{-1}$ via peristaltic pumps (Cole Parmer). The total gas flow rate was maintained at $19.2 \mathrm{~mL} \mathrm{~min}^{-1}$ with different flow rates of $\mathrm{CO}_{2}, \mathrm{Ar}$ (Keengas, 99.999\%), and $\mathrm{NO}_{\mathrm{x}}$. For instance, 83.3\% $\mathrm{CO}_{2}$ and $16.7 \% \mathrm{Ar}$ was prepared by flowing $16 \mathrm{~mL} \mathrm{~min}^{-1} \mathrm{CO}_{2}$ and $3.2 \mathrm{~mL}$ $\mathrm{min}^{-1}$ Ar via Brooks GF40 mass flow controllers. $83.3 \% \mathrm{CO}_{2}, 15.87 \% \mathrm{Ar}$, and $0.83 \%$ $\mathrm{NO}_{\mathrm{x}}$ were prepared by flowing $16 \mathrm{~mL} \mathrm{~min}^{-1} \mathrm{CO}_{2}$ with $3.2 \mathrm{~mL} \mathrm{~min}^{-1}$ of $5 \% \mathrm{NO} / \mathrm{Ar}$ (Matheson Gas) or $3.2 \mathrm{~mL} \mathrm{~min}^{-1}$ of $5 \% \mathrm{NO}_{2} / \mathrm{Ar}$ (Matheson Gas) using a $50 \mathrm{~mL}$ gastight syringe (1050 SL, Hamilton) via a syringe pump (New Era Pump Systems). Syringes were quickly switched to another syringe before running out of gases. Similarly, $83.3 \% \mathrm{CO}_{2}, 15.87 \% \mathrm{Ar}$, and $0.83 \% \mathrm{~N}_{2} \mathrm{O}$ were prepared by flowing $16 \mathrm{~mL}$ $\mathrm{min}^{-1} \mathrm{CO}_{2}, 3.04 \mathrm{~mL} \mathrm{~min}^{-1} \mathrm{Ar}$, and $0.16 \mathrm{~mL} \mathrm{~min}^{-1} \mathrm{~N}_{2} \mathrm{O}$ (99.99\%, Matheson Gas). $\mathrm{N}_{2} \mathrm{O}$ was fed by using a $10 \mathrm{~mL}$ gastight syringe (1010 SL, Hamilton) via a syringe pump (Cole Parmer). For $\mathrm{NO}_{2}$ experiment, the gas outlet of the electrolyzer was connected to $2 \mathrm{M} \mathrm{KOH}$ (85\%, Sigma-Aldrich) to scrub the remaining $\mathrm{NO}_{2}$ and additional Ar was flowed at $16 \mathrm{~mL} \mathrm{~min}^{-1}$ to carry the $\mathrm{CO}_{2} \mathrm{RR}$ products to the GC. $\mathrm{CV}$ and chronopotentiometry experiments were conducted via an Autolab PG128N. For CV measurements, the electrodes were pre-reduced at $100 \mathrm{~mA} \mathrm{~cm}^{-2}$ in $83.3 \% \mathrm{CO}_{2}$ and $16.7 \% \mathrm{Ar}$ for $10 \mathrm{~min}$. The half-cell potentials were measured with respect to $\mathrm{Ag} / \mathrm{AgCl}$ reference electrode (Pine Research) and calculated to the RHE scale in which $\mathrm{E}($ vs. RHE) $=\mathrm{E}($ vs. Ag/AgCl) $+0.209 \mathrm{~V}+0.0591 \mathrm{~V} \times \mathrm{pH}-$ $\eta_{\text {IRdrop. }}$ The $\mathrm{pH}$ was measured at the outlet of the catholyte channel. The resistance was measured with the current-interrupt technique ${ }^{40}$, and the measured potential was manually post IR-corrected.

Product quantification. The gas products were analyzed via a multiple gas analyzer no. 5 gas chromatography system (SRI Instruments) equipped with a Molsieve $5 \mathrm{~A}$ and a HayeSep D column connected to a thermal conductivity detector (TCD) and a flame ionization detector (FID). Ar was used as a carrier gas with a flow rate of $19 \mathrm{~mL} \mathrm{~min}^{-1}$ and $1 \mathrm{~mL}$ of sample was automatically loaded to the column. The gas sample was loaded to $0.5 \mathrm{~m}$ HaySep D pre-column connected to $2 \mathrm{~m}$ Molsieve $5 \mathrm{~A}$ column at $0.050 \mathrm{~min}$. At $0.490 \mathrm{~min}$, any molecule remaining in the HaySep D precolumn was backflushed out to vent. At $2.150 \mathrm{~min}$, the gas sample was automatically loaded to $2 \mathrm{~m}$ HaySep D column. The column temperature was maintained at $35^{\circ} \mathrm{C}$ for $2.950 \mathrm{~min}$, increased to $210^{\circ} \mathrm{C}$ at $40^{\circ} \mathrm{C} / \mathrm{min}$, and maintained at $210^{\circ} \mathrm{C}$ until the end of the analysis. A typical GC analyses of potential $\mathrm{CO}_{2} \mathrm{RR}$ products, $\mathrm{N}_{2}, \mathrm{NO}$, and $\mathrm{N}_{2} \mathrm{O}$ are provided in Supplementary Fig. $38.2 \% \mathrm{H}_{2}$, $1 \% \mathrm{CO}, 1 \% \mathrm{CH}_{4}, 1 \% \mathrm{C}_{2} \mathrm{H}_{4}, 0.50 \% \mathrm{C}_{2} \mathrm{H}_{6}, 0.25 \% \mathrm{C}_{3} \mathrm{H}_{6}, 0.25 \% \mathrm{C}_{3} \mathrm{H}_{8}$ in Ar (Matheson) was used to obtain the chromatogram of potential $\mathrm{CO}_{2} \mathrm{RR}$ products.

The liquid $\mathrm{CO}_{2} \mathrm{RR}$ products were analyzed via ${ }^{1} \mathrm{H}$ nuclear magnetic resonance (NMR) with water suppression using a presaturation method (Bruker AVIII 600 $\mathrm{MHz}$ NMR spectrometer). The liquid sample was collected at the outlet of the electrolyzer and diluted to $25 \%$ in deionized water (DI). $500 \mu \mathrm{L}$ of the diluted sample was mixed with $100 \mu \mathrm{L}$ of $25 \mathrm{ppm}$ (volume \%) dimethyl sulfoxide (99.9\%, Alfa Aesar), which was used as an internal standard, in $\mathrm{D}_{2} \mathrm{O}$.

$\mathrm{NH}_{3}$ was quantified using indophenol blue method ${ }^{41}$ with UV-vis spectroscopy (Nanodrop 2000, Thermo Scientific). $100 \mu \mathrm{L}$ of the sample was mixed with $500 \mu \mathrm{L}$ of alkaline hypochlorite solution (A1727, Sigma-Aldrich) and $500 \mu \mathrm{L}$ of phenol nitroprusside solution (P6994, Sigma-Aldrich). The solution was incubated in the dark at room temperature for $20 \mathrm{~min}$. $2 \mu \mathrm{L}$ of the solution was pipetted onto the pedestal, and the absorbance was measured by UV-vis spectroscopy from $190 \mathrm{~nm}$ to $840 \mathrm{~nm}$. The absorbance of the sample was measured at $630 \mathrm{~nm}$, and the absorbance measured at $830 \mathrm{~nm}$ was subtracted to remove the background. The calibration curves were obtained using different concentrations of ammounium hydroxide $\left(\mathrm{NH}_{4} \mathrm{OH}\right.$ 28.0-30.0\%, Sigma Aldrich) in $0.25 \mathrm{M} \mathrm{KHCO}_{3}$ (Supplementary Fig. 13).

$\mathrm{NH}_{2} \mathrm{OH}$ was quantified using a procedure modified from a procedure reported by Afkhami et al ${ }^{42}$. with UV-vis spectroscopy (Nanodrop 2000, Thermo Scientific). Neutral red solution was prepared by dissolving $200 \mathrm{mg}$ of neutral red (SigmaAldrich) in $100 \mathrm{~mL}$ DI. Iodate solution was prepared by dissolving $1.00 \mathrm{~g}$ of potassium iodate $\left(\mathrm{KIO}_{3}, 99.995 \%\right.$, Sigma-Aldrich) in $100 \mathrm{~mL}$ DI. A total of $500 \mu \mathrm{L}$ of sample was mixed with $250 \mu \mathrm{L}$ of $3.0 \mathrm{M}$ sulfuric acid (Fisher Scientific) and 250 $\mu \mathrm{L}$ of iodate solution. After $5 \mathrm{~min}$ at room temperature, $500 \mu \mathrm{L}$ of neutral red solution was added to the solution. The solution was incubated at room temperature for $20 \mathrm{~min}$. In total $2 \mu \mathrm{L}$ of the solution was pipetted onto the pedestal, and the absorbance was measured by UV-vis spectroscopy from $190 \mathrm{~nm}$ to 840 $\mathrm{nm}$. The absorbance of the sample was measured at $510 \mathrm{~nm}$, and the absorbance measured at $800 \mathrm{~nm}$ was subtracted to remove the background. The change in absorbance was determined by subtracting the absorbance of the sample solution from the absorbance of the solution with $0 \mathrm{mg} \mathrm{L}^{-1} \mathrm{NH}_{2} \mathrm{OH}$. The calibration curves were obtained using different concentrations of hydroxylamine (50 wt \% in $\mathrm{H}_{2} \mathrm{O}$, Sigma Aldrich) in $0.25 \mathrm{M} \mathrm{KHCO}_{3}$ (Supplementary Fig. 14).

Flow electrochemical mass spectrometry (FEMS). An identical flow cell with an entrance for the MS probe at the top of the gas channel was used for the FEMS measurement (Supplementary Fig. 16). The probe consisted of a PEEK capillary with inner diameter of $0.25 \mathrm{~mm}$ with PTFE membrane attached at the tip of the capillary. The PTFE membrane with a pore size of $200 \mu \mathrm{m}$ was used to prevent the entry of aqueous electrolyte, while allowing gaseous and volatile products to enter the MS chamber. The distance between the probe and the cathode was kept constant. The electrodes were pre-reduced at $10 \mathrm{~mA} \mathrm{~cm}^{-2}$ for $5 \mathrm{~min}$ in Ar before the introduction of $0.83 \%$ NO. The products were detected by a Hiden Quadrupole mass spectrometer (MS). The mass fragments were detected by a secondary electron detection voltage of $1700 \mathrm{~V}$ with an ionization potential of $70 \mathrm{eV}$ and emission current of 200 A. $m / z$ of interest was tracked over the course of the experiment, in which a constant potential was applied for approximately 2 min starting at $t=1.5$ min. For the deconvolution of $m / z=17$ signal, $m / z=17$ signal from the water was first determined using $\mathrm{m} / z=18$ signal. Next, the contribution from water to $\mathrm{m} / z=$ 17 signal was subtracted from the observed $m / z=17$ signals to obtain the signal from ammonia. For the deconvolution of $\mathrm{m} / z=28$ and 44 signals, $\mathrm{m} / z=28$ and 44 signals from $\mathrm{CO}_{2}$ in the electrolyte was first determined using $m / z=12$ signal. $m / z=12$ signal was smoothed using the Savitzsky-Golay method with a window of 30 data points to reduce the oscillations in the signal prior to deconvolution. Next, the contributions from $\mathrm{CO}_{2}$ to $m / z=28$ and 44 were 
subtracted from the observed $\mathrm{m} / z=28$ and 44 signals to obtain the signals from NORR products. $m / z=44$ signal corresponded to the signal from $\mathrm{N}_{2} \mathrm{O}$, and this was used to calculate the contribution of $\mathrm{N}_{2} \mathrm{O}$ to $\mathrm{m} / z=28$ and 30. Lastly, the contributions of $\mathrm{N}_{2} \mathrm{O}$ to $m / z=28$ and 30 were subtracted from the $m / z=28$ and 30 signals from NORR products, respectively, to yield $\mathrm{N}_{2}$ and $\mathrm{NO}$ signals, respectively. All deconvolution was conducted using MATLAB. Mass spectra of $\mathrm{NH}_{4} \mathrm{OH}, \mathrm{NO}, \mathrm{N}_{2} \mathrm{O}, \mathrm{N}_{2}, \mathrm{H}_{2} \mathrm{O}$, and $\mathrm{CO}_{2}$ used for the deconvolution were obtained using the same MS equipment (Supplementary Fig. 17).

Material characterization. For SEM and XPS measurements, the electrodes were first taken out of the electrolyzer after electrolysis at desired time points. The electrodes were dried in the vacuum oven (MTI Corporation) for up to three days before SEM images were acquired with Auriga 60 CrossBeam $(1.5 \mathrm{kV})$. The electrodes were quickly transported to the XPS equipment (K-alpha Alpha X-ray photoelectron spectrometer system, Thermo Fisher Scientific) after drying in the vacuum oven for $5 \mathrm{~min}$. The electrodes were exposed to air for less than $20 \mathrm{~min}$. High-resolution XPS measurements were obtained at pass energy of $20 \mathrm{eV}$ with a step size of $0.1 \mathrm{eV}$. Flood gun was turned on. $\mathrm{Cu} 2 \mathrm{p}, \mathrm{Ag} 3 \mathrm{~d}$, and Sn $3 \mathrm{~d}$ were scanned 10 times while $\mathrm{N} 1 \mathrm{~s}$ was scanned 30 times. Four different spots were scanned and averaged. All peaks were fitted using Thermo Avantage software with adventitious carbon referenced to the Cls peak at $284.8 \mathrm{eV}$.

XAS measurement was performed at the 8-ID Beamline of the National Synchrotron Light Source II at Brookhaven National Laboratory (BNL). The electrodes were taken out of the electrolyzer at $1 \mathrm{~h}$ (after exposure to $\mathrm{NO}_{\mathrm{x}}$ for $0.5 \mathrm{~h}$ ) during a $100 \mathrm{~mA} \mathrm{~cm}^{-1}$ constant current $\mathrm{CO}_{2} \mathrm{RR}$ experiment with the introduction of $\mathrm{NO}_{\mathrm{x}}$ (Fig. 2a-c and Supplementary Figs. 6 and 7). In the case of $\mathrm{NO}_{2}$, the samples were exposed to $0.23 \% \mathrm{NO}_{2}$ instead due to the availability of the gas at the time of the experiment. The electrodes were quickly stored in vials filled with $\mathrm{Ar}$ and the vials were tightly sealed with Parafilm at the home institution. The electrodes were transported to the Brookhaven National Laboratory (New York, USA) and were loaded into a XAS batch cell, which was fabricated from Teflon and 304 stainless steel, with a Kapton film window for high transmissivity for X-ray measurements (Supplementary Fig. 31). The electrodes were exposed to air for $\sim 20$ min before the measurement. Pt wire and $\mathrm{Ag} / \mathrm{AgCl}$ were used as a counter and a reference electrode, respectively. $1 \mathrm{M} \mathrm{KHCO}_{3}$ was used as an electrolyte and $\mathrm{CO}_{2}$ was flowed at $10 \mathrm{~mL} \mathrm{~min}^{-1}$. XAS data were analyzed using the IFEFFIT package, which included ATHENA and ARTEMIS ${ }^{43}$.

\section{Data availability}

All data needed to evaluate the conclusions in the paper are present in the paper and/or the Supplementary Materials. Additional data related to this paper may be requested from the authors.

Received: 7 May 2020; Accepted: 28 October 2020;

Published online: 17 November 2020

\section{References}

1. Chen, C., Khosrowabadi Kotyk, J. F. \& Sheehan, S. W. Progress toward commercial application of electrochemical carbon dioxide reduction. Chemistry 4, 2571-2586 (2018).

2. De Luna, P. et al. What would it take for renewably powered electrosynthesis to displace petrochemical processes? Science 364, eaav3506 (2019).

3. $\mathrm{Lu}, \mathrm{Q}$. et al. A selective and efficient electrocatalyst for carbon dioxide reduction. Nat. Commun. 5, 1-6 (2014).

4. Zhang, S., Kang, P. \& Meyer, T. J. Nanostructured tin catalysts for selective electrochemical reduction of carbon dioxide to formate. J. Am. Chem. Soc. 136, 1734-1737 (2014)

5. Dinh, C. T. et al. $\mathrm{CO}_{2}$ electroreduction to ethylene via hydroxide-mediated copper catalysis at an abrupt interface. Science 360, 783-787 (2018).

6. Kuhl, K. P. et al. Electrocatalytic conversion of carbon dioxide to methane and methanol on transition metal surfaces. J. Am. Chem. Soc. 136, 14107-14113 (2014).

7. Hori, Y., Wakebe, H. H. I., Tsukamoto, T. \& Koga, O. Electrocatalytic process of $\mathrm{CO}$ selectivity in electrochemical reduction of $\mathrm{CO}_{2}$ at metal electrodes in aqueous media. Electrochim. Acta 39, 1833-1839 (1994).

8. Jouny, M., Luc, W. \& Jiao, F. General techno-economic analysis of $\mathrm{CO}_{2}$ electrolysis systems. Ind. Eng. Chem. Res. 57, 2165-2177 (2018).

9. Endrödi, B. et al. Multilayer electrolyzer stack converts carbon dioxide to gas products at high pressure with high efficiency. ACS Energy Lett. 4, 1770-1777 (2019).

10. Arquer, F. P. G. De et al. $\mathrm{CO}_{2}$ electrolysis to multicarbon products at activities greater than $1 \mathrm{~A} \mathrm{~cm}^{-2}$. Science 367, 661-666 (2020).

11. Koytsoumpa, E. I., Bergins, C. \& Kakaras, E. The $\mathrm{CO}_{2}$ economy: review of $\mathrm{CO}_{2}$ capture and reuse technologies. J. Supercrit. Fluids 132, 3-16 (2018).
12. D’Alessandro, D. M., Smit, B. \& Long, J. R. Carbon dioxide capture: prospects for new materials. Angew. Chem. Int. Ed. 49, 6058-6082 (2010).

13. Last, G.V., Schmick, M. T. Identification and Selection of Major Carbon Dioxide Stream Compositions. (Pacific Northwest National Laboratory, 2011)

14. Metz, B., Davidson, O., Coninck, De, H. C., Loss, M. \& Meyer, L. A. IPCC Special Report on Carbon Dioxide Capture and Storage. (Cambridge University Press: Cambridge, UK, 2005) 442.

15. Luc, W. et al. $\mathrm{SO}_{2}$-induced selectivity change in $\mathrm{CO}_{2}$ electroreduction. J. Am. Chem. Soc. 141, 9902-9909 (2019).

16. Williams, K. et al. Protecting effect of mass transport during electrochemical reduction of oxygenated carbon dioxide feedstocks. Sustain. Energy Fuels 3, 1225-1232 (2019).

17. Wang, $\mathrm{X}$. et al. Mechanistic reaction pathways of enhanced ethylene yields during electroreduction of $\mathrm{CO}_{2}-\mathrm{CO}$ co-feeds on $\mathrm{Cu}$ and $\mathrm{Cu}$-tandem electrocatalysts. Nat. Nanotechnol. 14, 1063-1070 (2019).

18. Komatsu, S., Tanaka, M., Okumura, A. \& Kungi, A. Preparation of $\mathrm{Cu}$-solid polymer electrolyte composite electrodes and application to gas-phase electrochemical reduction of $\mathrm{CO}_{2}$. Electrochim. Acta 40, 745-753 (1995).

19. Zhai, Y., Chiachiarelli, L. \& Sridhar, N. Effect of gaseous impurities on the electrochemical reduction of $\mathrm{CO}_{2}$ on copper electrodes. ECS Trans. 9, 1-13 (2009).

20. $\mathrm{Xu}, \mathrm{Y}$. et al. Oxygen-tolerant electroproduction of $\mathrm{C}_{2}$ products from simulated flue gas. Energy Environ. Sci. 13, 554-561 (2020).

21. Engelbrecht, A., Hämmerle, M., Moos, R., Fleischer, M. \& Schmid, G. Improvement of the selectivity of the electrochemical conversion of $\mathrm{CO}_{2}$ to hydrocarbons using cupreous electrodes with in-situ oxidation by oxygen. Electrochim. Acta 224, 642-648 (2017).

22. Gholami, F., Tomas, M., Gholami, Z. \& Vakili, M. Technologies for the nitrogen oxides reduction from flue gas: a review. Sci. Total Environ. 714, 136712 (2020).

23. Skalska, K., Miller, J. S. \& Ledakowicz, S. Trends in NOx abatement: a review. Sci. Total Environ. 408, 3976-3989 (2010).

24. Jouny, M., Luc, W. \& Jiao, F. High-rate electroreduction of carbon monoxide to multi-carbon products. Nat. Catal. 1, 748-755 (2018).

25. Kudo, A. \& Mine, A. Kudo et al 1997 - Electrocatalytic reduction of nitrous oxide on metal and oxide.pdf. Appl. Surf. Sci. 121/122, 538-542 (1997).

26. Long, J. et al. Direct electrochemical ammonia synthesis from nitric oxide. Angew. Chemie Int. Ed. 59, 2-10 (2020).

27. Finlayson-Pitts, B. J., Wingen, L. M., Sumner, A. L., Syomin, D. \& Ramazan K. A. The heterogeneous hydrolysis of $\mathrm{NO}_{2}$ in laboratory systems and in outdoor and indoor atmospheres: an integrated mechanism. Phys. Chem. Chem. Phys. 5, 223-242 (2003).

28. Soto-Hernández, J. et al. Electrochemical reduction of NOx species at the interface of nanostructured $\mathrm{Pd}$ and $\mathrm{PdCu}$ catalysts in alkaline conditions. Appl. Catal. B Environ. 259, 118048 (2019).

29. Rosca, V., Duca, M., DeGroot, M. T. \& Koper, M. T. M. Nitrogen cycle electrocatalysis. Chem. Rev. 109, 2209-2244 (2009).

30. Yang, J., Kwon, Y., Duca, M. \& Koper, M. T. M. Combining voltammetry and ion chromatography: application to the selective reduction of nitrate on Pt and PtSn electrodes. Anal. Chem. 85, 7645-7649 (2013).

31. Clark, E. L., Singh, M. R., Kwon, Y. \& Bell, A. T. Differential electrochemical mass spectrometer cell design for online quantification of products produced during electrochemical reduction of $\mathrm{CO}_{2}$. Anal. Chem. 87, 8013-8020 (2015).

32. Schouten, K. J. P., Qin, Z., Gallent, E. P. \& Koper, M. T. M. Two pathways for the formation of ethylene in $\mathrm{CO}$ reduction on single-crystal copper electrodes. J. Am. Chem. Soc. 134, 9864-9867 (2012).

33. Arán-Ais, R. M., Scholten, F., Kunze, S., Rizo, R. \& Roldan Cuenya, B. The role of in situ generated morphological motifs and $\mathrm{Cu}(\mathrm{i})$ species in $\mathrm{C}_{2+}$ product selectivity during $\mathrm{CO}_{2}$ pulsed electroreduction. Nat. Energy 5, 317-325 (2020).

34. Zhang, Z. et al. Synthesis of monodisperse silver nanoparticles for ink-jet printed flexible electronics. Nanotechnology 22, 425601 (2011).

35. Xian, J., Hua, Q., Jiang, Z., Ma, Y. \& Huang, W. Size-dependent interaction of the poly(N-vinyl-2-pyrrolidone) capping ligand with Pd nanocrystals. Langmuir 28, 6736-6741 (2012).

36. Inagaki, M., Toyoda, M., Soneda, Y. \& Morishita, T. Nitrogen-doped carbon materials. Carbon 132, 104-140 (2018).

37. Lazar, P., Mach, R. \& Otyepka, M. Spectroscopic fingerprints of graphitic, pyrrolic, pyridinic, and chemisorbed nitrogen in N-Doped graphene. J. Phys. Chem. C 123, 10695-10702 (2019).

38. Wu, H. \& Chen, W. Copper nitride nanocubes: Size-controlled synthesis and application as cathode catalyst in alkaline fuel cells. J. Am. Chem. Soc. 133, 15236-15239 (2011).

39. Qu, F., Yuan, Y. \& Yang, M. Programmed synthesis of $\mathrm{Sn}_{3} \mathrm{~N}_{4}$ nanoparticles via a soft chemistry approach with urea: application for ethanol vapor sensing. Chem. Mater. 29, 969-974 (2017).

40. Liu, K., Smith, W. A. \& Burdyny, T. Introductory guide to assembling and operating gas diffusion electrodes for electrochemical $\mathrm{CO}_{2}$ reduction. ACS Energy Lett. 4, 639-643 (2019). 
41. Andersen, S. Z. et al. A rigorous electrochemical ammonia synthesis protocol with quantitative isotope measurements. Nature 570, 504-508 (2019).

42. Afkhami, A., Madrakian, T. \& Maleki, A. Indirect kinetic spectrophotometric determination of hydroxylamine based on its reaction with iodate. Anal. Sci. 22, 329-331 (2006).

43. Ravel, B. \& Newville, M. ATHENA, ARTEMIS, HEPHAESTUS: data analysis for X-ray absorption spectroscopy using IFEFFIT. J. Synchrotron Radiat. 12, 537-541 (2005).

\section{Acknowledgments}

This material is based upon work supported by the Department of Energy under Award DE-FE0029868. The authors also thank the National Science Foundation for financial support (Award CBET-1803200). This research used resources at the 8-ID Beamline of the National Synchrotron Light Source II, a US Department of Energy Office of Science User Facility operated by Brookhaven National Laboratory under contract no. DESC0012704. The authors acknowledge E. Stavitski (8-ID Beamline, NSLS-II, Brookhaven National Laboratory) for assistance in X-ray absorption spectroscopy measurements.

\section{Author contributions}

F.J. supervised the whole project. B.K. and F.J. designed the experiments and collectively wrote the paper. B.K. conducted the electrochemical and XPS measurements. B.K. and W.C. prepared electrodes. B.K. and B.H. performed the FEMS study. H.S. conducted the SEM measurements. H.S., E.J., and S.O. performed the XAS experiments. All authors commented on the manuscript.

\section{Competing interests}

The authors declare no competing interests.

\section{Additional information}

Supplementary information is available for this paper at https://doi.org/10.1038/s41467020-19731-8.

Correspondence and requests for materials should be addressed to F.J.

Peer review information Nature Communications thanks the anonymous reviewers for their contribution to the peer review of this work. Peer reviewer reports are available.

Reprints and permission information is available at http://www.nature.com/reprints

Publisher's note Springer Nature remains neutral with regard to jurisdictional claims in published maps and institutional affiliations.

(c) Open Access This article is licensed under a Creative Common Attribution 4.0 International License, which permits use, sharing adaptation, distribution and reproduction in any medium or format, as long as you give appropriate credit to the original author(s) and the source, provide a link to the Creative Commons license, and indicate if changes were made. The images or other third party material in this article are included in the article's Creative Commons license, unless indicated otherwise in a credit line to the material. If material is not included in the article's Creative Commons license and your intended use is not permitted by statutory regulation or exceeds the permitted use, you will need to obtain permission directly from the copyright holder. To view a copy of this license, visit http://creativecommons.org/ licenses/by/4.0/.

(C) The Author(s) 2020 